\title{
USING FACEBOOK AND WHATSAPP TO LEVERAGE LEARNER PARTICIPATION AND TRANSFORM PEDAGOGY AT THE OPEN UNIVERSITY OF INDONESIA
}

\author{
Susilo, Adhi \\ Open University of Indonesia \\ Use of ICT in course delivery
}

\begin{abstract}
ABSTRAK
Facebook (FB) dan WhatsApp (WA) telah menjadi "portal komunikasi" untuk jaringan sosial, yang telah dengan cepat mengubah cara orang berkomunikasi dan tetap terhubung. Dari perspektif pendidikan, situs jejaring sosial telah menerima ulasan ambigu. Beberapa penelitian telah menunjukkan bahwa penggunaan FB menjadi lebih luas dalam pembelajaran bahasa dan dapat menjadi alat yang efektif. FB tidak hanya mudah digunakan, tetapi juga membantu mendorong belajar mandiri dalam lingkungan sosial bagi siswa dan menempatkan kontrol untuk belajar ke tangan siswa. Artikel ini berfokus pada situs jejaring sosial FB, dan aplikasi WA dalam konteks UT. la mencoba untuk menjelaskan kegiatan berbagi informasi dilakukan melalui diskusi online menggunakan FB dan kelompok WA dan melibatkan siswa pembelajaran jarak jauh. Penelitian ini meneliti partisipasi siswa dalam diskusi online dan umpan balik mereka pada penggunaan FB dan forum WA sebagai platform untuk activity. FB dan WA diadopsi untuk mendukung tutorial online di Universitas Terbuka Indonesia dengan tujuan untuk meningkatkan guru-murid dan partisipasi rekanberbasis, dan meningkatkan pengiriman pedagogis dan pembelajaran inklusif di ruang formal dan informal. Temuan menunjukkan FB dan WA berubah pedagogi dengan meningkatkan lingkungan sosial konstruktif untuk guru-siswa dan rekan-berbasis cokonstruksi pengetahuan. Peran guru berubah dari instruktur untuk fasilitator dan mentor memberikan bimbingan pada permintaan. Peran mahasiswa juga berubah dari penerima informasi ke generator informasi, kolaborator, organizer informasi / pencari / pemberi, pemikir kritis dan pemimpin kelompok. Namun tantangan menggunakan Facebook dan WhatsApp termasuk guru 'kebencian penggabungan akademik dan keluarga hidup disebabkan oleh konsultasi WhatsApp setelah jam.
\end{abstract}

Kata kunci: Facebook, Jarak siswa belajar, situs jejaring sosial , WhatsApp

\begin{abstract}
Facebook (FB) and WhatsApp (WA) have become the "communication portal" for social networking, which has rapidly transformed the way people communicate and stay connected. From an educational perspective, social networking sites have received ambiguous reviews. Some studies have shown that the use of FB is becoming more widespread in language learning and it can be an effective tool. FB is not only easy to use, but it also helps encourage autonomous learning within a social environment for students and puts control for learning into the students' hands. This article focuses on the social networking site, FB, and WA application within the context of UT. It attempts to shed light on an information-sharing activity conducted via online discussion using FB and WA groups and involving distance learning students. This study investigated students' participation in the online discussion and their feedback on the use of FB's and WA's forums as the platform for the activity.FB and WA were adopted for supporting an online tutorial at the
\end{abstract}


Open University of Indonesia with a view to heighten tutor-student and peer-based participation, and enhance pedagogical delivery and inclusive learning in formal and informal spaces. The findings suggest FB and WA transformed pedagogy by fostering social constructivist environments for tutor-student and peer-based co-construction of knowledge. The teacher's role was transformed from an instructor to a facilitator and mentor providing guidance on demand. Student roles were also transformed from information receivers to information generators, collaborators, information organizer/seekers/givers, critical thinkers and group leaders. However, the challenges of using Facebook and WhatsApp included tutor' resentment of the merging of academic and family life occasioned by WhatsApp consultations after hours.

Keywords: distance learning student, Facebook, social networking site, WhatsApp

Internet as one of information and communication technology element has a great impact to human life. People especially in big cities are used to watching television, to communicate via mobile phone, social networking, texting via the internet, as well as visiting various portals or website without any limitations. According to Ludlow and Duff (2009), the Internet has had a more dramatic influence on education than any previous technological innovation because it has allowed individuals of all ages to access education and training programs. However, the most dramatic changes have come most recently with the introduction of Web 2.0. Web 2.0 is a set of web-based applications that are fluid in nature (Lorenzetti, 2009). Its basic elements are communication and collaborative technologies that involve voice, video, social networking, and content sharing; the direction and content of these applications are established by their users.

The study focused on use of the FB as a social networking site and WhatsApp for distance education at an Indonesian distance university, the Open University of Indonesia (Universitas Terbuka or UT). It investigated students' participation in online discussions and their feedback on the use of FB and WhatsApp groups as the platform for the activity. The application of WhatsApp which combine the smartphone and internet connection offers many advantages for language learning. Many students that have Facebook and WhatsApp running on their mobile always think about its capacity as a social networking and chatting platform and less people are thinking about how this mobile application can be effectively use for education collaboration and learning. It is also very few people use it for language learning. In fact, we can use WhatsApp hidden features for education and learning, including English language learning. Based on these ideas, the writer would like to focus on English language learning using Facebook and WhatsApp application. The purpose of the study is twofold: (1) to explore the pedagogical value of Facebook and WhatsApp services, particularly its potential to enhance academic participation of all learners and transform lecturers'teaching practices and (2) examine its capacity to breach the digital divide among learners in geographically dispersed informal contexts. An informing framework comprising Facebook and WhatsApp enabled lecturerstudent and student-peer consultations was drawn upon to explore the potential of social networking to promote equitable participation in diverse informal spaces.

\section{THEORETICAL MODEL}

The FRAME model

Koole (2009) proposes a Framework for the Rational Analysis of Mobile Education (FRAME) to grasp learning that emerges from the convergence of mobile technologies, learning capacities and 
social interaction. The FRAME model conceives collaborative construction of knowledge inmobile contexts as dependent on the intersection of interactions (between individuals, dyads, groups), and mediation of conversational technology (see Figure 1).

As shown in Figure 1, the device aspect (D) refers to the physical, technical and functional characteristics of mobile devices, which invariably affect the interface between the mobile learner and the learning task(s) (Koole, 2009). The learner aspect $(L)$ underscores the cognitive abilities, memory, prior knowledge, emotions and possible motivations of the individual learner. It emphasises understanding how learners use prior knowledge to encode, store and transfer information.

Mobile learners in a mobile instant messaging (MIM) context bring tacit, peer-based and pedagogical content knowledge and perspectives to their dialogic conversations via networked devices. The social aspect (S) constitutes the seedbed of interaction and cooperation. Lecturers and learners must adhere to the rules of engagement and cooperation, which enable information exchange, knowledge construction and sustenance of cultural practices.

Koole (2009)suggests that device usability intersection (DL) draws on considerations from both device aspect functionalities and individual/collective individuals' attributes. It foregrounds technology's technical aspects, which impact on users' cognitive demands and psychological satisfaction, thus influencing their cognitive load, access to information and ability to traversedifferent physical and virtual locations.

Social technology intersection (DS) emphasises devices' capacity to trigger and sustain communication and collaboration among multiple individuals and systems. Device technical capabilities such as short messaging service, telephony and Internet access directly influence information exchange and collaboration between people with diverse needs, intentions and priorities (Koole, 2009). In addition, the interaction learning intersection (LS) synthesises learning and instructional theories and rides on social constructivism philosophy.

Mobile learning is therefore a combination of the interactions between learners, their devices, and other people. Koole also provides a helpful checklist for institutions looking to adopt mobile learning, including the following questions:

1. How the use of mobile devices might change the process of interaction between learners, communities, and systems?

2. how learners may most effectively use mobile access to other learners, systems, and devices to recognize and evaluate information and processes to achieve their goals?

3. how can learners become more independent in navigating through and filtering information?

4. how the roles of teachers and learners will change and how to prepare them for that change? 


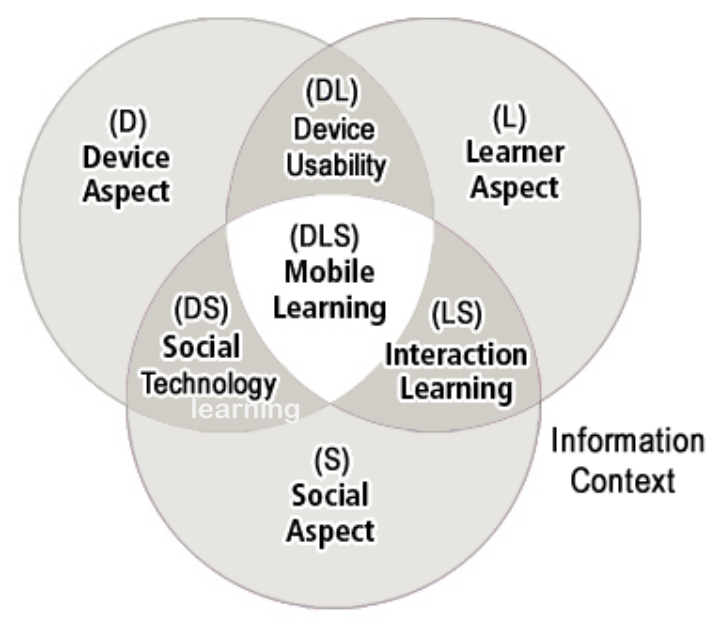

Figure 1: The FRAME model (Koole, 2009, p. 27)

\section{LITERATURE REVIEW}

UT is a state university for Indonesia dedicated to open and distance learning. UT provides online tutorials ("Tuton") as an alternative to face-to-face tutorials, particularly for students who have access to the Internet; the tutorials motivate students to be self-directed and independent learners. Online tutorials facilitate two-way asynchronous communication and offer interactive human contact to distance learners (Suparman, 2007). Online tutorials at UT are mandatory for graduate students but voluntary for undergraduate students.

UT's online tutorials are delivered through a learning management system (LMS), which is a software application used to plan, implement, and assess a specific learning process (Techtarget, 2005). An LMS consists of a wide range of Internet-based pedagogical and course administration tools integrated within a single platform. WebCT, Blackboard, Desire to Learn, E-College, Moodle, and Sakai are some of the more popular LMS platforms. Typically, an LMS provides a tutor with a way to create and deliver content, monitor student participation, and assess student performance (Techtarget, 2005).

UT currently uses Moodle as its LMS. Although Moodle has the capacity for synchronous and asynchronous online discussions in chat rooms and discussion boards, students seldom use these features because of a lack of tutor presence and because of inconvenient aspects of the Moodle platform. The more that students access the platform, the slower the system becomes, which can be troublesome for students trying to take quizzes, submit assignments, or just simply access the course content. The website can also shut down on occasion, blocking students from accessing course materials. As an alternative, UT students sometimes choose to use FB as a communication channel to support learning in online tutorials.

\section{The Net Generation}

Worley (2011) and others have stated that today's higher education faculty and administrators face a challenge with their students, many of whom are part of what is known as the Net Generation (Net Gen). "Net Generation" or "Digital Natives" develop cognitively in a manner different from previous generations as a result of their living in the digital age (Evans, 1995; Rovai, Ponton, \& Baker, 2008). Prensky (2001, p. 1) defines today's students as "native speakers" of the 
digital language of computers, video games and the Internet. They are called digital immigrants (Prensky, 2001).

One of the greatest challenges for Net Gen learning will be in the area of technology in education. As students become more technologically advanced, faculty must be technologically ready to meet student needs, but many university faculty and administrators are from earlier generations and are more familiar with learning and teaching styles that are different from those of the Net Generation. In addition, the life experiences, expectations, and technological expertise of many faculty and the students they are to teach are significantly different. Traditional methods of instruction will no longer work in a society that has encountered "a paradigm shift from emphasizing teaching to emphasizing learning" (Wilson, 2004, p. 59). In the new learning paradigm, the mission and purpose of education is to produce learning, not to deliver instruction. The role of faculty is to design learning methods and environments, rather than to be primarily lecturers.

Faculty must be aware of these differences, and must prepare to adjust their teaching philosophies and practices for a new breed of learners (Worley, 2011). According to Jeff and Zane (2008), Net Gen students possess certain key traits that translate into processes for learning in school. They prefer working collaboratively, do not respond well to the lecture, often do not communicate effectively by traditional standards, require information individually tailored to them, and require readily available technology. Wilson (2004) recommends active learning for enhancing teaching effectiveness for Net Gen students. Using active learning strategies such as discussions, reflection activities, group projects and cooperative problem-solving can deepen students' understanding of course material and their ability to apply new ideas. Since Net Geners have a team orientation, they should benefit greatly from active learning opportunities.

\section{Using mobile instant messaging to leverage learner participation and transform pedagogy}

One of the most complicated academic endeavours in transmission pedagogies is to generate democratic participation of all students and public expression of silenced voices. While the potential of mobile phones, particularly mobile instant messaging (MIM), to trigger broadened academic participation is increasingly acknowledged in literature, integrating MIM into classrooms and out-of-the-classroom tasks has often been confronted with academic resistance. Academic uncertainty about MIM is often predicated on its perceived distractive nature and potential to trigger off-task social behaviours (Rambe \& Bere, 2013). WhatsApp was adopted for an information technology course at a South African university with a view to heighten lecturer-student and peerbased participation, and enhance pedagogical delivery and inclusive learning in formal (lectures) and informal spaces. Rambe and Bere (2013) suggested heightened student participation, the fostering of learning communities for knowledge creation and progressive shifts in the lecturer's mode of pedagogical delivery. However, the concomitant challenge of using MIM included mature adults' resentment of the merging of academic and family life occasioned by WhatsApp consultations after hours. Students also expressed ambivalence about MIM's wide-scale roll-out in different academic programmes.

\section{Social Networking}

Boyd and Ellison $(2007$, p. 2) define social networks as "web-based services that allow individuals to: (1) construct a public or semi-public profile within a bounded system, (2) articulate a list of other users with whom they share a connection, and (3) view and traverse their list of connections and those made by others within the system." FB is the most current and widely used social network. 
FB was originally designed for college students, but is now open to anyone 13 years of age or older. FB users can create and customize their own profiles with photos, videos, and information about themselves (Conole, 2010).

Facebook (FB) was created in 2004 by Mark Zuckerberg at Harvard University. The name for FB came from the publications that some colleges pass out to students at the beginning of the year to help students get to know each other better. FB, synonymous with social media among school and university students, could be described as the most popular social networking tool in history (Omar, Embi, \& Yunus, 2012). It has the highest number of visitors among all the social networking tools available in Web 2.0, with approximately a billion active users worldwide (Facebook, 2012). Like most online social networking sites, FB's mission is to make the world more open and connected. People use FB to stay connected with friends and family, to discover what's going on in the world, and to share and express what matters to them (Bosch, 2009).

Students, particularly female students, may be inherently motivated to feel connected to others within a virtual environment (Cheung \& Lee, 2011). Creating a virtual community of students is therefore likely to improve their intention to use the online learning technology. Cheung and Lee also found that attitude of female students has the strongest direct effect on their behavioral intention to use an Internet-based learning medium. They concluded that perceived enjoyment influences attitude more strongly for female students than it influences male students.

\section{Teaching and Learning with FB}

FB has potential for teaching and learning because of its unique built-in functions that offer pedagogical, social and technological affordances (Wang, 2008; Wang \& Woo, 2007; Wang, Woo, Quek, Yang, \& Liu, 2012). Wang et al. (2012) explored the function of a FB group as an LMS and the students' perceptions of using it in their courses. In this study, the FB group was used in two courses at a teacher education institute in Singapore as a learning management system for posting announcements, sharing resources, organizing weekly tutorials and conducting online discussions. Wang et al. revealed that students were basically satisfied with the pedagogical, social and technological affordances of FB, as the fundamental functions of an LMS could be easily implemented in the FB group. However, using the FB group as an LMS had certain limitations. It did not support directly uploading files in some formats, and the discussion was not organized in a threaded structure. Also, the students did not feel safe and comfortable as their privacy might be compromised.

Grainne Conole (2011) investigated English as a Second Language (ESL) learners' participation in an information-sharing task conducted via FB groups and their feedback on the use of FB groups as the platform for the activity. A group of 31 learners taking a communication course at a public university participated in the study. Thematic analysis revealed that the use of FB as a platform for the information-sharing task received very positive feedback from the participants, suggesting that it is a promising virtual tool and environment to promote interaction in English learning. The authors suggested that more activities using FB groups should be assigned for learners to practice and use communicative language. In addition, they recommended promoting awareness of available online tools and modelling effective use of the tools to help enhance learners' online interactions. The findings of Conole's study support the work of Selwyn (2009), who argued that FBuse must be seen as being situated within the 'identity politics' of being a student. In particular, FB appears to provide a ready space where the 'role conflict' that students often experience in their relationships with 
university work, teaching staff, academic conventions, and expectations can be worked through in a relatively closed 'backstage' area.

Friedman and Gale (2011) provides us with an up-to-date insight into young people's attitudes towards writing. Most young people write regularly and young people write technologybased materials, such as text and instant messages, most frequently. While owning a mobile phone does not appear to alter young people's writing behaviour, having a profile on a social networking site or having a blog is connected to enjoyment of writing and confidence in writing. Young people today use computers regularly and believe that computers are beneficial to their writing. They believe it is paramount that the school curriculum reflects and utilizes writing forms that young people enjoy and engage with, in order to demonstrate that writing is more than a compulsory task: it is an essential life skill.

In summary, these studies show that FB and WA have the potential: (1) for teaching and learning because of its unique built-in functions that offer pedagogical, social and technological affordances; (2) to be used for online academic discussions, either as an alternative to LMSs commonly used in distance education or to complement such platforms; and (3) to create a promising virtual tool and environment to promote interaction in English language learning.

\section{METHODOLOGY \\ The Case Study}

The case study involved second-year English Translation students undertaking a Writing III course at English Literature study program in UT Indonesia. Given the study's focus on exploring Facebook and WhatsApp's potential to fosterdigital inclusion, a technology-based module provided an ideal context for such an investigation. The lecturer observed that question-based lecturer-student and peer-based engagements inclass were very limited due to limited contact time, perceived transactional distance between thelecturer and students, and low self-esteem students' lack of confidence in addressing the lecturer'squestions publicly due to potential ridicule by peers. The lecturer introducedWhatsApp, MIMapplication to boost participation, and interaction lasted for a semester.WhatsApp did not replacedidactic teaching but served to extend academic consultation during and after hours. For thelecturer, this project constituted community engagement, and hence he was not paid for hisinteraction with students. More than 100 students enrolled in online tutorial for the Writing III course, although only 10 participatedin this study.

\section{Virtual Ethnography}

The primary methods used for the study were virtual ethnography, online qualitative interviews, and content analysis of 10 UT students' FB and WA profiles. Virtual ethnography is the practice of ethnography, but in a virtual or online setting (Bosch, 2009). Ethnography involves "a holistic description of cultural environment" (Singer, 2009). It entails studying people within their own cultural environment through intensive fieldwork and involves in-depth investigation. The focus of research was on undergraduate students, as they are generally the heaviest FB users (Mazman \& Usluel, 2010; Stutzman, 2008). The researcher contacted the students to ask for permission to do an analysis of their FB pages and to participate in an interview.

The virtual ethnography approach employed in this study identified key markers for further exploration in the online interviews. The population consists of 10 students in their third semester. The students' contact information was provided by the UT Information Technology department. The data were collected from a threaded online discussion, links postings, friend lists, groups and 
networks, wall posts, and other asynchronous communication via WhatsApp. Also, several tutors were interviewed informally to validate the findings from the student interviews.

The UT students' FB group had been established before the start of the study. The process of adapting FB to provide e-learning support started about six months later through a FB group created by the students and moderated by senior students. From the very beginning, the students invited other students to join their FB group to access course-related materials, which required the moderator's approval. At the time of the study there were more than 200 members in the group. The FB group's wall mainly provided news about recent topics from online tutorial, some of which were related to the various course activities; via the 'home' page of FB group, the researcher was also able to learn the status of the students from time to time. The researcher was able to gain access to their FB pages because the moderator invited the researcher to join this FB group. In addition, the group members requested the researcher to accept friend requests from them. The roles of the researcher in this group were as a tutor, a learning materials provider, and a facilitator.

The interview questionnaires were pre-tested with participants to provide information on the acceptability of the language. Pre-testing reduces errors by improving survey questions (Creswell \& Plano Clark, 2011). In the pre-testing, the researcher noted the time spent and the way in which the questions were received, misunderstandings that occurred, and terms that were not understood. Field testing was conducted after the pre-testing; the field test consisted of a full test of the survey instrument and procedures, including the introduction, explaining the participant's rights based on ethics requirements, consent, conducting the interview, and closing the interview. The final version of interview instrument was used in online interviews using Skype (video conferencing software), and Evaer (audio and video recorder software).

The researcher interviewed the 10 students for approximately 30 minutes each. The questions covered internet availability, how the students used FB and WA to support online tutorials, how students' social networks on FBvand WA related to their educational network in their online tutorials, how students attempted to engage with lecturers using FB and WA, and what potential FB and WA holds for building learning communities in distance education. Specifically, the researcher wished to uncover the characteristics, opinions, perceptions and usage of FB for a group of UT's students.

This study was informed by the notion that participation in a social network site leaves online 'traces' that reveal users' attitudes, social relationships and affiliations in offline networks (Gráinne Conole, 2011a). Text provides the discursive space for the presentation of self to others. The challenge in studying life online can be complicated by the interference of the researcher in the frame of the field, and by the power of the researcher in representing the culture (Markham, 2005). In this case, sites were viewed where access was not controlled by privacy settings. Despite potential ethical challenges, the virtual ethnography was essential to define the field and triangulate the findings from the interviews and surveys. Respondents' confidentiality was guaranteed, as this component of the research was intended to provide an overview of trends, with no specific references to the content on individuals' pages. This study uses the term 'virtual ethnography' quite loosely, and more accurately merely draws on the basic principles of ethnography, with the researcher employing a form of 'lurking' or 'completely unobtrusive observation' (Garcia, Standlee, Bechkoff, \& Cui, 2009, p. 58) to gain an understanding of online interaction. In an attempt to counter some of the negatives associated with this methodology, nothing was actually 'harvested' (Sharf, 1999) and no posts or messages from pages viewed are cited in this article. 


\section{RESULTS AND DISCUSSION}

All of the 10 research participants were female students. The participants often updated their status in FB. They would voluntarily share FB information with each other and become online 'friends,' often using the site to replicate classroom networks and to informally share online tutorialrelated questions and discussions. It also appeared that many participants did not change their privacy settings, allowing all members of the network to view their current status.

To understand the influence of WhatsApp on student academic participation, pedagogical deliveryand digital inclusion implications, the FRAME framework concepts, device usability, socialtechnology, interaction learning were drawn upon to interpret interview transcriptions and thepatterns of student responses to questionnaires. FRAME's concepts were also put into conversationwith raw data (interview transcriptions and survey results) to provide a nuanced account ofMobile Instant Messaging's (MIM's) influence on pedagogical considerations and digital inclusion. The subsequent sectionspresent the findings and the discussion based on these concepts.

\section{Device usability}

Under this theme, technological issues' interplay with student participation is discussed under thefollowing: device portability, information availability and student psychological comfort. These issuesare discussed in subsequent sections.

\section{a. Portability}

Two subcategories emerged under portability: mobile learning and context free access to learningresources. Student appropriation of WhatsApp-enabled phones for lecturer-student and peerbasedconsultations leveraged their participation as they redressed poor connectivity via institutionalnetworks. Device portability coupled with affordances for anywhere anytime access toinformation and learning resources redressed the constraints distance, space and temporal timesin access to resources.

Facebook and WhatsApp-mediated learning's support for multiple access to learning resources impactedstudents' ability to engage with peers and the educator synchronously. Mobile devices' personalisationand adaptation to different contexts ensured persistent supply of texts, information andlearning resources, which enabled networked learning and multiple peer-based feedbacks. Theinformal, convenient context for instantaneous sharing of vital academic information activatedby the "porting" of learning resources across different spaces extended learning times and augmentedtraditional consultation spaces.

Facebook and WhatsApp's affordances for asynchronous communication also directly impacted studentparticipation. The retrievability of messages posted when students were offline, outside networkcoverage or when their devices were switched off implied that they could participate any timeirrespective of context. Multiple interaction modes and diverse temporal times widened opportunitiesfor student involvement without missing conversation flows.

\section{b. Information availability}

Information availability comprised three subcategories: information synthesis-that WhatsApp'sdigital trails and discussion threads were more accessible, user friendly information repositoriesthan IT textbooks. The information divide, describes a social phenomenon in which off campusstudents with limited access to the libraries after hours, conceivedWhatsApp as breaching informationasymmetries they encountered due to their remote locations. It also rendered just-intimelearning through broadening access to navigable concepts and response summaries 
especiallywhen students were under pressure to complete multiple tasks simultaneously or during lastminutepreparations for examinations.

\section{c. Psychological comfort}

Facebook and WhatsApp also enhanced student psychological comfort in three main ways: reducing cognitiveload, minimising exam uncertainty and cognitive scaffolding. The lecturer and students' posting ofproblem-based questions that tested understanding of the practical application of concepts andtheoretical issues taught in class empowered students with critical assessment skills. Throughthese questioning practices, students gradually acclimatised to the educators' style of questioningabout IT concepts, allowing them to comfortably speculate/anticipate particular styles of questioningin exams. This modelling of particular questioning styles about concepts reduced theircognitive anxiety about being "caught off guard" and heightened student participation.

The platformalso enabled student cognitive scaffolding through group sharing of information andeased the pressure of individual problem solving and reflection. The statement under cognitive scaffoldingsuggests a shift in work ethic from individual accomplishment to collaborative coconstruction of knowledge (Rambe \& Bere, 2013). As Rambe (2012) suggests, the seamless integration of social practices, devices and platforms (eg, mobile phone platforms and texting culture) affords recursive engagements that potentially impact students' meaningful learning and (academically productive)connections.

Wider ownership of Facebook and WhatsApp-enabled phones contributed to broadened participation throughsustaining a critical questioning culture and information seeking practices. Facebook and WhatsApp anonymous communications bolstered the confidenceof shy students who conceived lectures as intimidating, hegemonic spaces that disruptedtransparent communication. The statement "As an confident student, the important thing aboutWhatsApp isits anonymous interactions. My confidence to give answers and post questions has improved because nobody ever knows" bears testimony to this psychological empowerment.WhatsApp, therefore,entrenched "participatory cultures" (Jenkins, 2010) which strongly support individual contentcreation, sharing and efficacy of personal connections.

\section{Social technology}

To unravel howstudent connectivity onWhatsApp can be harnessed to bridge exclusion in poorlynetworked communities, student access to mobile networks was interrogated under the socialtechnology theme. Under this theme, device connectivity and networked connectivity were the maincategories.

\section{a. Device connectivity}

Under this category some students emphasised the erratic nature of institutional networks (LMS), which triggered their dependence on mobile networks especiallyInternet. Other students complainedabout wireless connectivity's heavy reliance on the strength of connection signals acrosscampus, which compelled some to switch to their networked handhelds or walk in school to accessnetworks thus reinforcing the networked divide. This convergence of institutional and private networks presented by switching between networks challenges binary conceptions of the digitaldivide.

\section{b. Networked connectivity}

Student accessed WhatsApp through either WiFi-enabled networks or private virtual networks.Such mobile connections often provided slower connectivity compared with institutional networks.Student frustration with slow networked connectivity resonates with variations in 
thenetworked access to collectively generated resources. Notwithstanding the aforementioned drawbacks, productive device usage was not exclusively network dependent as collaborative learningcommunities and language of discourse were deeply implicated in productive engagements, affecting intensity and persistence of online interaction.

The main issue surrounding the use of FB at the students' workplace (i.e., their house) was related to time availability, since they were usually allowed to access the Internetonly during break times or after work. Some of the employers restricted or blocked their domestic employees' use of the Internet during work. Although the Internet was not always blocked in their houses, access was discouraged, with clear rules indicating to the employee (i.e., the domestic worker studyingwith UT) that access to the Internet was not allowed. Despite this, nearly all the students surveyed indicated that they accessed the Internet at home after work or during break time, with a smaller percentage indicating that they would only update their status using their mobile phones.

There was very little use of languages other than Indonesian language on students' walls, regardless of race or mother language. All communication was found to be in Indonesian, except posting in their English course group, with students considering this as the obvious choice of language for the medium.

Student accessed WhatsApp through either WiFi-enabled networks or private virtual networks.Such mobile connections often provided slower connectivity compared with home networks.Student frustration with slow networked connectivity resonates with variations in thenetworked access to collectively generated resources. Notwithstanding the aforementioned drawbacks, productive device usage was not exclusively network dependent as collaborative learningcommunities and language of discourse were deeply implicated in productive engagements, affecting intensity and persistence of online interaction.

\section{Interaction learning}

To address the question on the potential of WhatsApp to shift pedagogical delivery in informallearning contexts, the intricate interplay of interactants, situated m-learning contexts and in situcollaborative practice were explored under interactive learning category. Subcategories interaction,social cognition and learning communities, which merged through conversations with rawdata, are elaborated below.

\section{a. Interaction}

Facebook and WhatsApp Interaction unfolded in three main ways, namely lecturer-lecturer, learner-learner(student-peer) and student-content interactions. Lecturer-level engagements revolved aroundthe English lecturer's consultations with the guest lecturer (independent researcher) on FB and WAmediatedcourse design, tracking and interpreting students' learning trajectory via FB and WAenhancedinteractions. Although the guest lecturer was marginally involved in supportingstudent clusters, his constructive dialogue with the lecturer supported social constructivistinterpretations of student engagements. Both educators conceived these knowledgesharingpractices on online course design and student learning trajectory as team-based coaching thatmutually benefited their pedagogy. The English lecturer's online teaching strategy was also transformedby his personal reflections. These strategies helped transform pedagogical delivery froman authoritative, instructivist mode to a collaborative, connectivist approach.

At student-peer levels, the English lecturer discerned peer-based mentoring and student constructivistconstruction of knowledge through their intra-cluster collaborations on FB and WA. The studentswere more directly involved in knowledge construction and negotiation of perspectives as 
informationseekers, knowledge givers, information synthesisers and knowledge brokers. The lecturer'sfacilitative role through the summarisation of the main themes emerging from studentdiscussions suggest relaxed authority and a shift from transmission approaches of delivery toconstructivist approaches. These practices enabled students to assume more control and ownershipof the learning, For example, students who normally relied on private individual studyand avoided collaborative engagement found their "Ione wolf"(Bacon, Stewart, \& Stewart-Belle, 1998) mentality being subverted by FB and WA's demands for collaborative problem solving.

Survey data suggests that 10 respondents (100\%) preferred participating in FB and WA virtualforums to traditional classroom interaction. The higher preference of FB and WA to inclassdiscussions can be attributed to the anonymity of the online interactions, which potentiallydemocratised participation of shy and less confident students. FB and WA App "virtual classroom's"anonymous interaction, flexibility and affordances for personal reflection potentially liberated these subverted voices through provision of reflection time.

In general, FB is used by a wide range of students, in terms of race, class and gender. There was no evidence that FB use in this study differed from general Internet usage patterns in Hong Kong, probably because all students have equal access to the Internet via personal computers. However, what was most interesting is that while many students in this study had friends across racial groups, most tended to have friends who were similar to them in terms of race. Students' friends were mostly family and university acquaintances, but many also had friends from primary and secondary school. As a result, the numbers of friends ranged from around 16 to over 800 . Students in the study had been registered in FB for periods of one to three years. This research thus supports international studies which show that participation in online networks tends to follow cultural and linguistic lines (Boyd, 2008).

Student use ofFB is quite varied, and one cannot assume that students use online social networking tools in homogenous ways. Generally, several categories of users were noted: some signed up to FB but were not daily active users; some signed up but did not actively participate, even though they often observed on the site, reading information posted by their friends; and some were active users, uploading and downloading information and using a variety of applications on the site, predominantly for social purposes. Within the latter category, there was a further divide between those who usedFB for social purposes only, and those who also usedFB for some kind of academic conversations, though these were usually linked to classes in which this type of participation was a course requirement. Another category of user was defined by those who did not use the site for much other than keeping friends abreast of their activities by frequently updating their status messages. Students updated their status frequently, particularly before and after a weekend, because they usually had one day off every week on Sunday.

The UT students in this study regardedFBas an academic support. It was noted that first-year students who joined UT in Hong Kong immediately signed up to join the English group in FB. UT students usedFB for social networking, seeking support from peers, community building in a virtual class, and the students' notice board. This finding is consistent withresearch by Bosch (2009) and Tina (2010), who found that FB for social networking worked as a complement to online courses. It also confirms comments by Selwyn (2009)related to student management of identity and role conflicts.One of the student comments: "The peers' answers seemed to work quite well, my own feedback was interesting and informative, hopefully the feedback I gave was useful". One student described how she had to be strategic in her selection of activities when she was offered five different discussion boards in FB group from which to choose. She chose one of them and stuck with it, stating 
that many students had done the same and that she had seen the same names coming up again day after day. She found the discussion to be very stimulating and she was surprised at how much she enjoyed reading other peer's ideas in spite of the range of skill level.

WhatsApp-mediated learning's support for multiple accesses to learning resources impactedstudents' ability to engage with peers and the tutor synchronously. Smartphone' personalisationand adaptation to different contexts ensured persistent supply of texts, information andlearning resources, which enabled networked learning and multiple peer-based feedbacks. Theinformal, convenient context for instantaneous sharing of vital academic information activatedby the "porting" of learning resources across different spaces extended learning times and augmentedtraditional consultation spaces.

WhatsApp's affordances for asynchronous communication also directly impacted studentparticipation. The retrievability of messages posted when students were offline, outside networkcoverage or when their devices were switched off implied that they could participate any timeirrespective of context. Multiple interaction modes and diverse temporal times widened opportunitiesfor student involvement without missing conversation flows.

Students believed that FB and WA discussion forumsallowed them to reflect "deeply" on questions and queries before giving their opinions. This ispotentially attributable to forums' asynchronous nature that mitigated the pressure of instant,spontaneous responses immanent in lecture interactions (Rambe \& Bere, 2013).

\section{b. Social cognition}

This encapsulated the situated context of social technology usage and mental modelling of participatingaudiences in FB and WA mediated interactions. Content delivery via the LMS andFB/WA created authentic situated contexts for knowledge sharing that were accommodativeof students' varying circumstances and asymmetrical access to networks. Questionnairesresponses affirmed that 100 participants (100\%) preferred the flexibility and spontaneity of FB and WA discussions to prepacked content and inflexible lectures.

Social cognition also manifested in students' claim that addressing the lecturers' questions onFB and WA helped them to gain transferable assessment skills like his style of questioning aboutconcepts and their corresponding responses. The statement "FB and WA enabled meaningful learningbecause the lecturer's and peer's posts on concepts allow us to understand how to respond to different concepts in thefinal exam" suggests student inductive discovery through critical questioning practices.

To cross-check these student claims about knowledge creation and transfer, survey questionssolicited responses on FB and WA discussions' potential to engender knowledge generation, reflectionand communication. Students' affirmative responses were knowledge creation, deep reflection and meaningful communication, suggesting FB and WA's forums'potential to foster "affinity spaces." For Gee (2004) "affinity spaces," are discursive spaces drivenbycommonendeavours to bridge (participation) differences linked to interact ants' interests, skillsandcapabilities.

\section{c. Learning communities}

This category had dialogue and the community of practice as it subcategories. The lecturerlecturerdialogic interactions involved the sharing of experiences, social practices and communicativerepertoires, thus fostering a community of practice and learner-centred teaching approaches. Forstudents, transformative learning played out in their critical engagement with learning resources. 
One common theme that was derived from the interviews was the development of learning communities using FB groups. FB's group tool provides opportunities for students to form groups in which they can support each other. These findings are consistent with studies by Koschmann (1994), Lao and Gonzales (2005), Tharp and Gallimore (1988), andWells and Chang-Wells (1992) that indicated that the Internet provides learning experiences and a place to build upon knowledge within a learning community. Online learning is a rich environment where learner-centered instructional techniques show opportunities for significant developments and offer new ways to learn, research, work and socialize (Bonk \& King, 1998; Gráinne Conole, 2011b).

UT students who were engaged in academic FB English groups actively participated in them and welcomed the use of the online social networking tool for academic,in addition to social, purposes. In most cases FB was reported as being useful. Students reflected that they were already spending much time on FB, and theywere able to check class-related material while at the same time engaging in personal communication. In general, students who used FB for various academic purposes, from the informal to the more formal mandatory participation, listed a range of benefits. Primarily, students said that their FB friends helped them to identify and find learning material on the Internet, and to answer questions about tasks in online tutorials (e.g., due dates, assignment details). Students also often used FB during weekends or break time for connecting with others to prepare face-to-face tutorials and to share lecture and study notes.

Respondents talked about how FB allowed them to learn from junior and senior students whom they had not yet meet in person. It also allowed them to network with groups that had similar academic interests, even if they were in different semesters/classes. The main benefit was being able to access different learning materials instantly in an informal and ubiquitous environment.

One participant felt that FB allowed students to ask questions that they might not feel comfortable asking in a formal online tutorial, as there is a relative higher degree of anonymity in the absence of asynchronous interaction. In response to informal questioning, some online tutors indicated that tasks/discussions were more effective because student queries had already been dealt with via the FB's group. Students used the FBgroup to indicate which areas of the particular material to cover or discuss, and then moved to the online tutorial LMS to answer the questions or tasks.

In many cases this kind of interaction was transferred to real face-to-face tutorial settings, as students felt their colleagues were more approachable after interacting with them online. In some ways FB could be perceived as a shared space-not controlled by them individually, but controlled by all together - thus breaking down the traditional power hierarchies among students. For example, there is no rule that the older control the younger. However, some experienced or smarter students often gave more comments in the group. This mechanism of community control could be positive; for example, if key people were absent from a group discussion, other students would assume their roles.

Each group had an administrator to manage the group; her primary task was to invite and approve group members, and then to provide links to learning materials. The secondary role of the administrator could be replaced by other members who have similar capabilities. In the process of course design and implementation, the administrator felt that it was easy to set up a FB group and have enough control. The administrator as a creator of a FB group could enroll or remove members easily. However, the administrator noted that it was quite troublesome to add learning materials because it involved uploading files with the 'Add File' menu, then putting the links into FB or pasting themdirectly into the group's wall. Also, FB does not support the direct uploading of some file formats. The administrator reported that moderating online discussions in the FB group was easy and that the 
topics of discussion were based on the topics in the online tutorial. These findings are similar to those of Wang et al. (2012), who used theFB group as a LMS. However, these authors noted that FBhad certain constraints; for example, it does not support the upload of some file formats, and discussions are not organized in a meaningful structure.

The student-tutor dialogic interactions involved the sharing of experiences, social practices and communicativerepertoires, thus fostering a community of practice and learner-centred teaching approaches. For students, transformative learning played out in their criticalengagement with learning resources. Students are suggesting FB and WA's forums' potential to foster "bridging spaces"-the space for connect differences linked to interactants' interests, skills and capabilities.

\section{Distractive technology}

Despite the academic value of Facebook and WhatsApp, lecturers expressed some reservationsabout facilitating discussion and receiving learning material 24/7. These tutors were both male and femalewith families who conceived the mobile application's blurring of contexts as "antisocial" anddisruptive of family life. However, the studentssupported the reception of academic material after hours. They indicated that such queries andresponses enabled them to revisit and visualise their lectures and saved them from looking upfor materials from libraries and books during late hours.

\section{CONCLUSION}

There are some advantages and disadvantages of using social networking in education including in English language learning. It can encourage students to engage with each other and to express and share their creativity and can create a better English communicative environment for students.

WhatsApp is not only sending text message but files and message broadcasting. We can share educational and learning resources and we can create broad based discussions on many subjects. We can ask questions in any subjects and send it across to all people in the group through a broadcast or start a meaningful discussion on concepts we need to understand much better. WhatsApp application can be used to learn the language skills such as reading and writing. However, this study is far from perfect and we welcome any further study on this matter.

The academic appropriation of Facebook and WhatsApp afforded the convergence of student individual traits (abilities, skills and capabilities), situated contexts and the conversational technology, which triggered their meaningful involvement in learning. Facebook and WhatsApp's anonymous, asynchronous collaborative learning allowed shy, less confident students to engage more productively. Althoughparticipation onlinewas higher than classrooms participation, some students became more vocalon Facebook and WhatsApp than in formal online tutorial as Facebook and WhatsApp afforded democratic expression through informationseeking, critical questioning and information sharing practices. Generally, the provision ofquestions and responses in different formats attracted the attention of students to participatemore. Although anonymity often raises uncertainty about learner's assumption of responsibilityfor their perspectives, this was mitigated by the educator's knowledge of all group members.

Lecturers with families, however, expressed ambivalence about Facebook and WhatsApp due to the contradiction between task demands for giving responses to students anytime, anywhere, and competing family commitments after-hours. 
Facebook and WhatsApp also transformed pedagogy by fostering social constructivist environments forlecturer-student and peer-based co-construction of knowledge. The lecturer's role was transformedfrom an instructor to a facilitator and mentor providing guidance on demand. Studentroles were also transformed from information receivers to information generators, collaborators, information seekers/givers, critical thinkers and group leaders

\section{REFERENCES}

Bacon, D. R., Stewart, K. A., \& Stewart-Belle, S. (1998). Exploring Predictors of Student Team Project Performance. Journal of Marketing Education, 20(1), 63-71. doi: 10.1177/027347539802000108

Bonk, C. J., \& King, K. S. (1998). Electronic collaborators: learner-centered technologies for literacy, apprenticeship, and discourse. Mahwah, N.J: L. Erlbuam Associates.

Bosch, T. E. (2009). Using online social networking for teaching and learning: Facebook use at the University of Cape Town. Communicatio, 35(2), 185-200. doi: 10.1080/02500160903250648

Boyd, D. (2008). Facebook's privacy trainwreck: Exposure, invasion, and social convergence. Convergence, 14(1), 13-20. doi: 10.1177/1354856507084416

Boyd, D., \& Ellison, N. B. (2007). Social network sites: Definition, history, and scholarship. Journal of Computer-Mediated Communication, 13(1), 210-230. doi: 10.1111/j.1083-6101.2007.00393.x

Cheung, C. M. K., \& Lee, M. K. O. (2011). Exploring the gender differences in student acceptance of an internet-based learning medium. In T. Teo (Ed.), Technology Acceptance in Education: Research and Issues (pp. 183-199). Rotterdam: Sense.

Conole, G. (2010). Facilitating New Forms of Discourse for Learning and Teaching: Harnessing the Power of Web 2.0 Practices. Open Learning, 25(2), 141-151. doi: 10.1080/02680511003787438

Conole, G. (2011). Editorial. Research in Learning Technology, 9(3). doi: 10.3402/rlt.v9i3.12032

Conole, G. (2011a). The evolving landscape of learning technology. Research in Learning Technology, 10(3). doi: 10.3402/rlt.v10i3.11407

Conole, G. (2011b). What constitutes good research in e-learning-are there lessons we can draw from the Research Assessment Exercise? Research in Learning Technology, 15(3). doi: 10.3402/rlt.v15i3.10929

Creswell, J. W., \& Plano Clark, V. L. (2011). Designing and conducting mixed methods research. Los Angeles: SAGE Publications.

Evans, T. (1995). Globalisation, post-Fordism and open and distance education. Distance Education, 16(2), 256-269. doi: 10.1080/0158791950160207

Facebook. (2012). Facebook Statistics. Retrieved September 24, 2012, from http://newsroom.fb.com/content/default.aspx?NewsAreald=22

Friedman, L. S., \& Gale, G. (2011). Social networking. Detroit: Greenhaven Press.

Garcia, A. C., Standlee, A. I., Bechkoff, J., \& Cui, Y. (2009). Ethnographic approaches to the internet and computer-mediated communication. Journal of Contemporary Ethnography, 38(1), 5284. doi: $10.1177 / 0891241607310839$

Gee, J. P. (2004). Situated language and learning: a critique of traditional schooling. London: Routledge.

Jeff, F., \& Zane, L. B. (2008). Training Generation N: how educators should approach the Net Generation. Education + Training, 50(6), 457-464. doi: 10.1108/00400910810901782 
Jenkins, H. (2010). Confronting the challenges of participatory cultures: media education for the 21 century. Chicago, II:: MacArthur.

Koole, M. (2009). A model for framing mobile learning. In M. Ally (Ed.), Mobile learning: transforming the delivery of education and training. Edmonton [Alta.]: AU Press.

Koschmann, T. D. (1994). Toward a theory of computer support for collaborative learning. Journal of the Learning Sciences, 3(3), 219-225. doi: 10.1207/s15327809jls0303_1

Lao, T., \& Gonzales, C. (2005). Understanding Online Learning through a Qualitative Description of Professors and Students' Experiences. Journal of Technology and Teacher Education, 13(3), 459-474.

Lorenzetti, J. (2009). Web 2.0 and course management systems. Distance Education Report, 13(5), $1-2$.

Ludlow, B. L., \& Duff, M. C. (2009). Evolution of distance education at West Virginia University: Past accomplishments, present activities, and future plans. Rural Special Education Quarterly, 28(3), 9.

Markham, A. (2005). The Methods, politics, and ethics of representation in online ethnography. In N. K. Denzin \& Y. S. Lincoln (Eds.), The SAGE handbook of qualitative research. Thousand Oaks: Sage Publications.

Mazman, S. G., \& Usluel, Y. K. (2010). Modeling educational usage of Facebook. Computers \& Education, 55(2), 444-453. doi: 10.1016/j.compedu.2010.02.008

Omar, H., Embi, M. A., \& Yunus, M. M. (2012). ESL Learners' Interaction in an Online Discussion via Facebook. Asian Social Science, 8(11).

Prensky, M. (2001). Digital natives, digital immigrants part 1. On the Horizon (Vol. 9, pp. 1-6): MCB University Press.

Rambe, P. (2012). Social Media-Enhanced Phones for Productive Learning of South African Postgraduate Students. International Journal of Mobile and Blended Learning (IJMBL), 4(2), 49-66. doi: 10.4018/jmbl.2012040104

Rambe, P., \& Bere, A. (2013). Using mobile instant messaging to leverage learner participation and transform pedagogy at a South African University of Technology. British Journal of Educational Technology, 44(4), 544-561. doi: 10.1111/bjet.12057

Rovai, A. P., Ponton, M. K., \& Baker, J. D. (2008). Distance learning in higher education: a programmatic approach to planning, design, instruction, evaluation, and accreditation. New York: Teachers College Press.

Selwyn, N. (2009). Faceworking: exploring students' education-related use of Facebook. Learning, Media and Technology, 34(2), 157-174. doi: 10.1080/17439880902923622

Sharf, B. (1999). Beyond netiquette: The ethics of doing naturalistic discourse research on the Internet. In S. Jones (Ed.), Doing Internet research: Critical issues and methods for examining the Net. Thousand Oaks, Calif: Sage Publications.

Singer, J. B. (2009). Ethnography. Journalism and Mass Communication Quarterly, 86(1), 191-198. doi: $10.1177 / 107769900908600112$

Stutzman, F. (2008). The vibrancy of online social spaces. In B. Rigby (Ed.), Mobilizing generation 2.0: a practical guide to using Web 2.0 technologies to recruit, organize, and engage youth. San Francisco: Jossey-Bass.

Suparman, A. (2007). The use of technology in distance education: Lessons learnt from the experience of Universitas Terbuka. Southeast Asian Journal on Open and Distance Learning, $5(3)$. 
Techtarget. (2005). What is learning management system (LMS)? . Retrieved June 3, 2012, from http://searchcio.techtarget.com/definition/learning-management-system

Tharp, R. G., \& Gallimore, R. (1988). Rousing minds to life: teaching, learning, and schooling in social context. Cambridge [Cambridgeshire]: Cambridge University Press.

Tina, L. I. M. (2010). The use of facebook for online discussions among distance learners. The Turkish Online Journal of Distance Education, 11(4), 72-81.

Wang, Q. (2008). A generic model for guiding the integration of ICT into teaching and learning. Innovations in Education and Teaching International, 45(4), 411-419.

Wang, Q., \& Woo, H. L. (2007). Comparing asynchronous online discussions and face-to-face discussions in a classroom setting. British Journal of Educational Technology, 38(2), 272286. doi: 10.1111/j.1467-8535.2006.00621.x

Wang, Q., Woo, H. L., Quek, C. L., Yang, Y., \& Liu, M. (2012). Using the Facebook group as a learning management system: An exploratory study. British Journal of Educational Technology, 43(3), 428-438. doi: 10.1111/j.1467-8535.2011.01195.x

Wells, C. G., \& Chang-Wells, G. L. (1992). Constructing knowledge together: classrooms as centers of inquiry and literacy. Portsmouth, $\mathrm{NH}$ : Heinemann.

Wilson, M. E. (2004). Teaching, learning, and millennial students. New Directions for Student Services, 2004(106), 59-71. doi: 10.1002/ss.125

Worley, K. (2011). Educating college students of the net generation. Adult Learning, 22(3), 31-39. 